\title{
Salinity Tolerance of 35 Bentgrass Cultivars
}

\author{
Kenneth B. Marcum ${ }^{1}$ \\ Department of Plant Sciences, University of Arizona, Tucson, AZ 85721-0036
}

Additional index words. Agrostis spp., turfgrass, salt tolerance

Abstract. Relative salinity tolerance of 33 creeping bentgrass (Agrostis palustris Huds), one colonial bentgrass (A. capillaris $L$.), and one velvet bentgrass (A. canina $L$.) cultivars were determined via hydroponics in a controlled-environment greenhouse. After gradual acclimation, grasses were exposed to moderate salinity stress $\left(8 \mathrm{dS} \cdot \mathrm{m}^{-1}\right)$ for 10 weeks to determine tolerance to chronic salinity stress. Relative dry weight of leaf clippings $(R L W)$, percentage of green leaf area (GL), root dry weight $(R W)$, and root length $(R L)$ were all effective parameters for predicting salinity tolerance. Following 10 weeks of salinity stress, RLW was correlated with GL $(r=0.72)$, with $R W(r=0.71)$, and with RL $(r=0.66)$. The range of salinity tolerance among cultivars was substantial. 'Mariner', 'Grand Prix', 'Seaside', and 'Seaside II' were salt-tolerant, 'L-93', 'Penn G-2', '18 Green', and 'Syn 96-1' were moderately salt tolerant, and 'Avalon', 'Ambrosia', 'SR1119', 'Regent', 'Putter', 'Penncross', and 'Penn G-6' were salt sensitive.

Rapid urban development has increased demands for limited freshwater supplies, prompting state and local government restrictions on the use of potable water for irrigating turfgrasses. In some western states, current laws require the use, when available, of saline secondary water sources (ex. effluent) for irrigating golf courses and other turf facilities (Arizona Dept. of Water Resources, 1995; California State Water Resources Control Board, 1990).

Bentgrasses (Agrostis sp.) are widely used on golf courses, bowling greens, and other intensively managed turfgrass facilities in the United States and throughout the world (Turgeon, 1996). Because of limited data, estimates of creeping bentgrass salinity tolerance have varied substantially. Species estimates vary from "good"-tolerant of 8-16 dS.m ${ }^{-1}$ ECe (saturated paste extract) (Harivandi, 1988; Horst and Beard, 1977), to "moderately tolerant"-tolerant of $8 \mathrm{dS} \cdot \mathrm{m}^{-1}$ ECe (Carrow and Duncan, 1998), to "moderately sensitive"-tolerant of 3-6 dS. $\mathrm{m}^{-1}$ ECe (Harivandi et al., 1992). As a species, colonial bentgrass has been classified as tolerant of ECe of $<4 \mathrm{dS} \cdot \mathrm{m}^{-1}$ (Harivandi et al., 1992), and velvet bentgrass tolerant of ECe of $<3 \mathrm{dS} \cdot \mathrm{m}^{-1}$ (Marcum, 1999).

Comparisons of bentgrass cultivars for salinity tolerance have been very limited. Substantial variation has been reported among natural populations of creeping bentgrass, with coastal populations being more tolerant than inland ones (Ahmad and Wainwright, 1977; Kik, 1989; Wu, 1981). In 1967,

Received for publication 14 Mar. 2000. Accepted for publication 14 Aug. 2000. I thank Virginia Lehman and Mohammad Pessarakli for their assistance. The cost of publishing this paper was defrayed in part by the payment of page charges. Under postal regulations, this paper therefore must be hereby marked advertisement solely to indicate this fact.

1E-mail address: kmarcum@ag.arizona.edu
Youngner et al. compared the salinity tolerance of seven turf cultivars of creeping bentgrass. Salinities resulting in 50\% shoot growth reduction ranged from ECs (solution) 9 to $26 \mathrm{dS} \cdot \mathrm{m}^{-1}$. Salinity tolerance decreased in the following order: 'Seaside', 'Arlington', 'Pennlu', 'Old Orchard', 'Congressional', 'Cohansey', and 'Penncross'. McCarty and Dudeck (1993) compared four creeping, one velvet, and two colonial bentgrasses for salinity tolerance during germination. 'Seaside' creeping bentgrass was most tolerant to salinity at the seedling stage, followed by 'Kingstown velvet', 'Exeter', and 'Highland colonial' bentgrass. Least tolerant were 'Pennlinks', 'Penncross', and 'Penneagle' creeping bentgrass. However, relative salinity tolerance during germination is not necessarily predictive of mature plant salinity tolerance (Shannon and Grieve, 1999). No other creeping bentgrass cultivar salinity trial has been published to date. The cultivars studied by Youngner et al. (1967) are no longer used to any extent by the turfgrass industry, with the exception of 'Penncross'. Because of the importance of bentgrasses to the turfgrass industry, a new generation of improved bentgrass cultivars has been developed by breeders. This study compares 35 modern bentgrass cultivars, popularly utilized by the turfgrass industry (L. Brilman, C. Edminster, V. Lehman, personal communication). The purpose of this study was to determine the degree and range of salinity tolerance present in modern bentgrass cultivars.

\section{Materials and Methods}

Thirty-three creeping, one velvet, and one colonial bentgrass cultivar (Table 1) were seeded at a rate of $7.3 \mathrm{~g} \cdot \mathrm{m}^{-2}$ into $7-\mathrm{cm}$-diameter $\times 8$-cm-deep pots filled with coarse, acid-washed silica (inert, neutral $\mathrm{pH}$ ) sand. Following germination under mist, pots were suspended over tubs containing $32 \mathrm{~L}$ of half- strength, constantly aerated Hoagland's no. 1 solution (Hoagland and Arnon, 1950), modified with Fe-sodium ferric diethylenetriamine pentaacetate (DTPA) chelate to provide 3 $\mathrm{mg} \cdot \mathrm{L}^{-1}$ elemental Fe. Pot bottoms consisted of coarse nylon screen, allowing roots to grow into the solutions. Plants were grown in a $29{ }^{\circ} \mathrm{C}$ day $/ 18{ }^{\circ} \mathrm{C}$ night greenhouse, with maximum photosynthetically active radiation (PAR) levels of $950 \mu \mathrm{mol} \cdot \mathrm{m}^{-2} \cdot \mathrm{s}^{-1}$. Light levels were supplemented for $2 \mathrm{~h}$ during early morning and late afternoon with high-pressure sodium lamps (1000 W; Energy Technics, York, Pa.). To ensure complete establishment, plants were grown for 2 months prior to initiation of salinity treatments.

Salinity levels were increased daily by $1 \mathrm{dS} \cdot \mathrm{m}^{-1}$ in treatment tubs (control tubs received no salt) using a salt mix of $75 \%$ $\mathrm{NaCl}: 25 \% \mathrm{CaCl}_{2}$ (w/w), until $8 \mathrm{dS} \cdot \mathrm{m}^{-1}$ was reached; at this point data collection began. Grasses were held at $8 \mathrm{dS} \cdot \mathrm{m}^{-1}$ for 10 weeks, during which relative dry weight of leaf clippings (RLW) and percentage of green

Table 1. Shoot salinity tolerance $(\mathrm{GL}=$ percentage of green leaf area; and RLW = relative dry weight of leaf clippings $\left.\mathrm{s}^{\mathrm{z}}\right)$ and rooting parameters $(\mathrm{RL}=$ root length; and RW = root dry weight) of 35 bentgrasses following 10 weeks exposure to $8 \mathrm{dS} \cdot \mathrm{m}^{-1}$ total salinity. Cultivars are creeping bentgrass, unless specified otherwise.

\begin{tabular}{|c|c|c|c|c|}
\hline \multirow[b]{2}{*}{ Cultivar } & \multicolumn{2}{|c|}{$\begin{array}{c}\text { Shoot } \\
\text { parameters }\end{array}$} & \multicolumn{2}{|c|}{$\begin{array}{c}\text { Root } \\
\text { parameters }\end{array}$} \\
\hline & $\begin{array}{l}\text { GL } \\
(\%)\end{array}$ & $\begin{array}{c}\text { RLW } \\
(\%)\end{array}$ & $\begin{array}{l}\mathrm{RL} \\
(\mathrm{cm})\end{array}$ & $\begin{array}{r}\mathrm{RW} \\
(\mathrm{mg}) \\
\end{array}$ \\
\hline Mariner & 33 & 43.5 & 18.2 & 132 \\
\hline Seaside II & 33 & 37.8 & 22.1 & 152 \\
\hline Grand Prix & 30 & 46.8 & 21.6 & 129 \\
\hline Seaside & 28 & 38.2 & 18.4 & 170 \\
\hline $18^{\text {th }}$ Green & 22 & 19.7 & 13.9 & 108 \\
\hline Century & 21 & 16.9 & 13.9 & 118 \\
\hline Backspin & 20 & 18.8 & 13.2 & 115 \\
\hline L-93 & 20 & 29.5 & 15.2 & 126 \\
\hline Penn G-2 & 17 & 28.4 & 13.5 & 139 \\
\hline Imperial & 15 & 13.8 & 16.4 & 113 \\
\hline Syn 96-1 & 15 & 19.2 & 14.0 & 110 \\
\hline Cobra & 12 & 10.1 & 12.4 & 94 \\
\hline Lopez & 10 & 17.1 & 13.1 & 109 \\
\hline Southshore & 10 & 11.2 & 8.9 & 103 \\
\hline Viper & 10 & 14.0 & 11.1 & 76 \\
\hline Penneagle & 9 & 12.1 & 6.4 & 64 \\
\hline Crenshaw & 8 & 14.8 & 10.4 & 103 \\
\hline Penn A-1 & 8 & 13.1 & 10.2 & 102 \\
\hline Penn A-2 & 8 & 12.5 & 11.8 & 115 \\
\hline SR1020 & 7 & 10.7 & 8.9 & 102 \\
\hline Penn A-4 & 6 & 10.0 & 13.4 & 111 \\
\hline Cato & 5 & 9.0 & 12.8 & 116 \\
\hline MSUEA & 5 & 9.5 & 10.4 & 99 \\
\hline Pennlinks & 5 & 8.5 & 13.2 & 92 \\
\hline MSUEB & 3 & 11.1 & 9.9 & 108 \\
\hline Providence & 3 & 9.7 & 10.1 & 74 \\
\hline Princeville & 2 & 1.1 & 12.5 & 61 \\
\hline Pro/Cup & 1 & 0.7 & 8.2 & 59 \\
\hline Penn G-6 & 0 & 0.0 & 8.9 & 102 \\
\hline Penncross & 0 & 0.0 & 10.6 & 100 \\
\hline Putter & 0 & 0.0 & 6.2 & 75 \\
\hline Regent & 0 & 0.0 & 10.6 & 103 \\
\hline SR1119 & 0 & 0.0 & 12.0 & 101 \\
\hline Ambrosia (colonial) & 0 & 0.0 & 0.8 & 9 \\
\hline Avalon (velvet) & 0 & 0.0 & 3.1 & 14 \\
\hline $\mathrm{LSD}_{0.05}$ & 11 & 8.8 & 6.4 & 33 \\
\hline
\end{tabular}

${ }^{2} \mathrm{RLW}=($ weight under salinity / weight under control) $\times 100$. 
leaf area $(\mathrm{GL})$ were recorded weekly [RLW = (treatment leaf dry weight/control leaf dry weight $\times 100$ ]. Solutions were monitored daily for salinity level using a model 2052 conductivity meter with platinum dip cell (VWR Scientific, Chicago), adjusted when necessary, and changed every $10 \mathrm{~d}$ to ensure minimal changes in nutrient ion concentrations.

Throughout experiments, grasses were clipped twice per week at $1-\mathrm{cm}$ height. Biweekly clippings were dried at $60{ }^{\circ} \mathrm{C}$ and combined for weekly dry weight determination. Root length (RL), i.e., distance from the crown to the longest extending root, and root dry weight (RW) were measured at the end of experiments. To ensure uniform starting conditions, roots were clipped back to the bottoms of the pots at the beginning of experiments.

Experimental design was a randomized complete block with four replications, each solution tub containing all 35 cultivars. Data were analyzed by analysis of variance, with mean separation by protected LSD at $P=0.05$. The RLW and GL data were transformed by arcsin prior to analysis (Steel and Torrie, 1980), but are presented as percentages. Pearson product moment correlation coefficients were used to compare variables. The experiment was repeated once. Results were similar and consistent between experiments, means of like variables being significantly correlated (average $r=0.7$ ). Therefore, all data are presented averages for both experiments.

\section{Results and Discussion}

Stress components include both level and time of exposure, with exposure time often being a more sensitive indicator of tolerance (Chen et al., 1982; Levitt, 1980). In this study, bentgrasses were held at a constant, moderate $\left(8 \mathrm{dS} \cdot \mathrm{m}^{-1}\right.$, Harivandi et al., 1992; Maas, 1990) stress level for 10 weeks to determine chronic salinity stress tolerance.

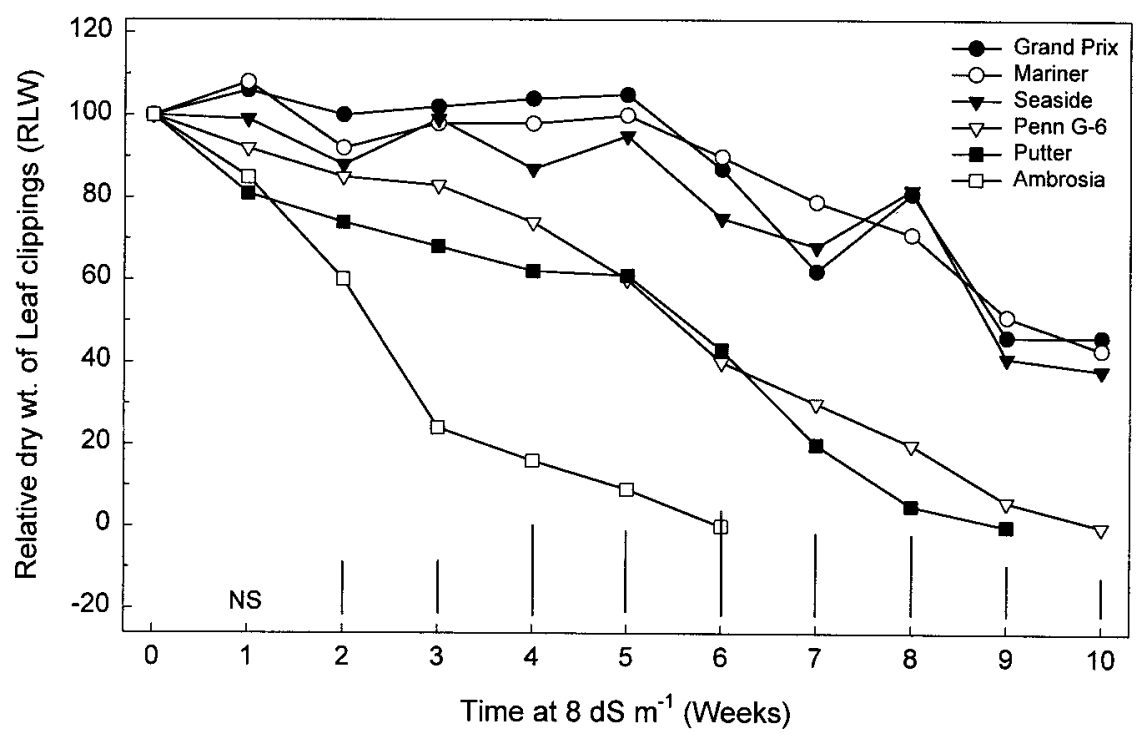

Fig. 1. Decline in weekly relative dry weight of leaf clippings (RLW) of six representative bentgrass cultivars with increasing exposure time to $8 \mathrm{dS} \cdot \mathrm{m}^{-1}$ total salinity. Vertical bars represent LSD values at $P \leq 0.05$.

the overall reduction in vigor under stress, relative to control conditions (Maas, 1990; van Genuchten and Hoffman, 1984). The RLW decreased as exposure time to salinity stress increased. As exposure time to stress increased, differences among cultivars became evident (Fig. 1). Following 10 weeks of exposure to $8 \mathrm{ds} \cdot \mathrm{m}^{-1}$, 'Grand Prix', 'Mariner', and 'Seaside' had the highest RLW (LSD, $P \leq 0.05$ ) (Table 1). However, 'Seaside II' was not significantly different from either 'Mariner' or 'Seaside', and 'L-93' was not significantly different from either 'Seaside' or 'Seaside II'.

Values of GL, a primary indicator of turfgrass quality (Morris and Shearman, 1999), were positively correlated $(r=0.72)$ with RLW (Table 2). 'Mariner', 'Seaside II', 'Grand Prix', 'Seaside', and ' $18^{\text {th }}$ Green' had the highest GL (Table 1). However, values for 'Century', 'Backspin', and 'L-93' were not significantly different from those for 'Grand Prix', 'Seaside', and ' $18^{\text {th }}$ Green'. Total shoot death $(\mathrm{GL}=0)$ occurred after 10 weeks of salinity stress in 'Penn G-6', 'Penncross', 'Regent', and 'SR1119', and at 9 weeks in 'Putter'. 'Ambrosia' (colonial bentgrass) and 'Avalon' (velvet bentgrass) suffered total shoot death after only 6 weeks of exposure. The salt tolerance of 'Seaside', and salt sensitivity of 'Penncross' are in agreement with values obtained by Youngner et al. (1967) and McCarty and Dudeck (1993).

The RW and RL were correlated with RLW ( $r=0.71$ and 0.66 , respectively), indicating the suitability of root growth parameters in estimating salinity tolerance (Table 2 ). However, rooting parameters RW and RL were not well correlated with GL. This is not too surprising, as GL is not a growth parameter, as is RLW. 'Seaside', 'Seaside II', and 'Penn G-2' were in the highest statistical
Table 2. Pearson product moment correlation coefficients, and associated probability levels for relative dry weight of leaf clippings (RLW), percentage of green leaf area (GL), root length (RL), and root dry weight (RDW) in bentgrass.

\begin{tabular}{llll}
\hline Variable & RLW & GL & RL \\
\hline GL & 0.72 & & \\
& 0.0001 & & \\
RL & 0.66 & 0.41 & \\
& 0.0001 & 0.0099 & \\
RDW & 0.71 & 0.46 & 0.83 \\
& 0.0001 & 0.0039 & 0.0001 \\
\hline
\end{tabular}

group for RW (Table 1). 'Mariner', 'Grand Prix', and 'L-93' were not statistically different from 'Seaside II' and 'Penn G-2'. 'Avalon' and 'Ambrosia' had lower RW values than did all other cultivars. Root dry weight and RL were strongly correlated with one another $(r=0.83$, Table 2$)$. Values of RL were highest in 'Seaside II', 'Grand Prix', 'Seaside', 'Mariner', and 'Imperial'.

This study revealed a substantial range in salinity tolerance present among modern bentgrass cultivars, indicating a high degree of genetic diversity within Agrostis. This indicates the potential for developing more salt-tolerant bentgrass cultivars through breeding. There was a relatively smooth decline in salinity tolerance among cultivars in this study, from salt-tolerant 'Mariner', 'Grand Prix', 'Seaside', and 'Seaside II', to moderately salt-tolerant 'L-93', 'Penn G-2', ' $18^{\text {th }}$ Green', and 'Syn 96-1', to salt-sensitive 'Avalon', 'Ambrosia', 'SR1119', 'Regent', 'Putter', 'Penncross', and 'Penn G-6'.

\section{Literature Cited}

Ahmad, I. and S.J. Wainwright. 1977. Tolerance to salt, partial anaerobiosis, and osmotic stress in Agrostis stolonifera. New Phytol. 79:605-612. Arizona Department of Water Resources. 1995. Modifications to the second management plan: 1990-2000.

California State Water Resources Control Board. 1990. California Water Code: Porter-Cologne Act provisions on reasonableness and reclamation promotion. Article number 13552.2:13577.

Carrow, R.N. and R.R. Duncan. 1998. Salt-affected turfgrass sites-Assessment and management. Ann Arbor Press, Chelsea, Mich.

Chen, H.H., Z.Y. Shen, and P.H. Li. 1982. Adaptability of crop plants to high temperature stress. Crop Sci. 22:719-725.

Harivandi, A. 1988. Irrigation water quality and turfgrass management. Calif. Turfgrass Culture 38(3-4).

Harivandi, M.A., J.D. Butler, and L. Wu. 1992. Salinity and turfgrass culture, p. 207-229. In: D.V. Waddington, R.N. Carrow, and R.C. Shearman (eds.). Turfgrass-Agron. Monogr. 32. Amer. Soc. Agron., Madison, Wis.

Hoagland, D.R. and D.I. Arnon. 1950. The waterculture method for growing plants without soil. Calif. Agr. Expt. Sta. Circular 347.

Horst, G. and J.B. Beard. 1977. Salinity in turf. Grounds Maintenance, Apr., p. 66, 69, 72, 73, 109 .

Kik, C. 1989. Ecological genetics of salt resistance 
in the clonal perennial, Agrostis stolonifera L. New Phytol. 113:453-458.

Levitt, J. 1980. Responses of plants to environmental stresses, Vol. II. Academic, New York.

Maas, E.V. 1990. Crop salt tolerance, p. 262-304. In: K.K. Tanji (ed.). Agricultural salinity assessment and management. ASCE Manuals and Reports on Engineering No. 71, ASCE, New York.

Marcum, K.B. 1999. Salinity tolerance in turfgrasses, p. 891-906. In: M. Pessarakli (ed.). Handbook of plant and crop stress. $2^{\text {nd }}$ ed. Marcel Dekker, New York.
McCarty, L.B. and A.E. Dudeck. 1993. Salinity effects on bentgrass germination. HortScience 28:15-17.

Morris, K.N. and R.C. Shearman. 1999. NTEP turfgrass evaluation guidelines. Natl. Turfgrass Evaluation Program, Beltsville, Md.

Shannon, M.C. and C.M. Grieve. 1999. Tolerance of vegetable crops to salinity. Scientia Hort. 78:5-38.

Steel, R.G.D. and J.H. Torrie. 1980. Principles and procedures of statistics, a biometrical approach. $2^{\text {nd }}$ ed. McGraw-Hill, New York.

Turgeon, A.J. 1996. Turfgrass management. $4^{\text {th }} \mathrm{ed}$.
Prentice Hall, Upper Saddle River, N.J.

van Genuchten, M.Th. and G.J. Hoffman. 1984. Analysis of crop salt tolerance data, p. 258-271. In: I. Shainberg and J. Shalhevet (eds.). Soil salinity under irrigation-Process and management. Springer-Verlag, New York.

Wu, L. 1981. The potential for evolution of salinity tolerance in Agrostis stolonifera L. and Agrostis tenuis Sibth. New Phytol. 89:471-486.

Youngner, V.B., O.R. Lunt, and F. Nudge. 1967. Salinity tolerance of seven varieties of creeping bentgrass, Agrostis palustris Huds. Agron. J. 59:335-336. 